\title{
Science loses cabinet seat after Australian election
}

Sydney. Australia's new conservative Coalition government has announced changes in its science policy arrangements following the general election at the beginning of this month. The Liberal and National Parties, linked in a coalition led by John Howard, won a resounding 46-seat majority over the 13-year-old Labor administration of the former prime minister, Paul Keating.

The new science and technology minister is Peter McGauran, a member of the National Party, which captured the rural vote. Unlike his predecessor, Peter Cook, who had a seat in the cabinet as a full Minister for Science, McGauran will be a junior minister in the large Department of Industry, Science and Tourism (DIST), and will attend cabinet meetings only when invited.

Some scientists are concerned that their activities are no longer directly represented in the cabinet. But few will be totally surprised at the new government's general approach, as McGauran is following a 20 page policy for science, engineering and technology, Investing in Tomorrow, which was issued in the final two weeks of the election campaign by Robert Hill, the coalition's spokesman on education and science.

The period since the election has heard a predictable outcry from the new government that the economy is in worse shape than it had realized, and that \$A8 billion (US\$6 billion) of expenditure has to be cut. Nevertheless, McGauran said last week that the government "will honour and implement all our commitments [in science], notwithstanding the deficit we inherited".

The coalition's financial promises total \$A190 million, including restoring \$A20 million per year to the triennial baseline funding of the Commonwealth Scientific and Industrial Research Organization, the country's main research agency, and an extra \$A90 million over three years for research infrastructure in universities. Funds for the
Australian Research Council's Collaborative Research Grants will increase by $\$ A 30$ million and postgraduate scholarships by $\$ A 9$ million over the same period.

Within the government itself, two bodies are being transferred to an enlarged Science Branch within DIST: the Prime Minister's Science and Engineering Council (PMSEC), an advisory body set up by former Labor Prime Minister, Bob Hawke, and the Australian Science and Technology Council, which will have engineering added to its name (to become ASTEC) and increase its role in analysing scientific performance.

Another significant shift, not hinted at in pre-election statements, has been the government's decision to move the post of chief scientist from the Prime Minister and Cabinet Department to DIST, and at the same time to enhance "the importance and status of the chief scientist with legislative authority to fulfil a cross-government role".

McGauran says he is consulting widely about the appointment of a chief scientist to succeed Michael Pitman, whose final term of office has come to an end. He points out that both PMSEC and the chief scientist will still have direct access to the prime minister, although observers see the moves as equivalent to a political downgrading. ASTEC, however, will have its own secretariat and will become "independent of government".

The Australian Research Council, which is at present part of the Education ministry and is responsible for providing competitive grants primarily to university researchers, will become a "separate body, quite independent of government", says McGauran. But there are signs that the council may become McGauran's responsibility, giving him what could be the most centralized role in the administration of science in Australian history, even though he will be lower in the ministerial pecking order than his predecessor.

Peter Pockley

\section{Telescope prospects looking dimmer}

Sydney. Peter McGauran, Australia's new science minister, warned last week that astronomers should not take for granted that the Coalition government will fully back their efforts to join the European Southern Observatory (ESO) project to construct and operate the Very Large Telescope (VLT) in Chile.

The hopes of astronomers had been raised during the election campaign that their application might be supported, whichever party won. Despite its rejection in the Innovation Statement published last December, Peter Cook, the former science minister, said that fund- ing the ESO application to the extent of years would have top priority for Labor in the August 1996 budget (see Nature 379, 668; 1996).

At the time, the opposition spokesman, Robert Hill, said he was happy for negotiations with ESO to continue. But Hill stopped short of matching the then-government's financial commitment. McGauran now says he "would seek independent advice of the size of the investment" before making any decision. "I warn against unreal expectations in the present economic climate." P. P. $A \$ 30$ million (US\$23 million) over five

\section{Resignation defuses Witwatersrand row over immunologist}

Cape Town. A fierce dispute between a black university administrator and faculty members at the University of the Witwatersrand in South Africa appears to have been defused by the decision of William Makgoba, a prominent research immunologist, to resign as the university's deputy vice-chancellor.

The move follows the signing of a 'memorandum of agreement' between Makgoba and nine of thirteen academics including ten deans - who last year accused him of embellishing his curriculum vitae, carrying out his administrative duties inadequately, and bringing the name of the university into disrepute (see Nature 378, 324; 1995).

The memorandum, which was accepted by the university's council last week, recommends that a tribunal that was to have investigated the claims against Makgoba should be scrapped. He will occupy a research professorship in the health sciences faculty for the remaining three and a half years of his contract.

The agreement between Makgoba and his critics follows the conclusion of a commission headed by Malcolm Wallis, chairman of the Senior Council of the Bar of South Africa, that Makgoba's counterallegations of tax evasion by the thirteen were groundless. In the memorandum, Makgoba apologizes for publicizing and misrepresenting information from their personal files.

In turn, the nine signatories to the memorandum acknowledge both that Makgoba "has made a significant and internationally-recognised contribution to immunology", and that the university had given him "inadequate support" in overcoming his relative lack of administrative and managerial experience. Makgoba, a South African who left the country after graduating in 1976, was recruited by the university 18 months ago from the Royal Postgraduate Medical School in London, where he was a senior lecturer.

The four remaining academics submitted a separate memorandum to the council, and have released a joint statement. They are unhappy about both the decision to scrap the tribunal and the fact that the memorandum does not exclude Makgoba from becoming the university's next vicechancellor when the present incumbent, Robert Charlton, retires next year.

But this outcome now appears unlikely. In justifying his resignation, Makgoba stated that he could not have worked with ten deans who did not want to work with him. He added that he knew "that I had to leave this office because I would not have been effective any longer". Michael Cherry 